\title{
Intestinal mucosal injury induced by tryptase-activated protease-activated receptor 2 requires $\beta$-arrestin- 2 in vitro
}

\author{
SHUN LI ${ }^{1 *}$, JIANQIANG GUAN $^{1 *}$, MIAN GE $^{1}$, PINJIE HUANG $^{1}$, YIQUAN LIN $^{2}$ and XIAOLIANG GAN ${ }^{2}$ \\ ${ }^{1}$ Department of Anesthesiology, The Third Affiliated Hospital, Sun Yat-sen University, Guangzhou, Guangdong 510630; \\ ${ }^{2}$ Department of Anesthesiology, Zhongshan Ophthalmic Center, Sun Yat-sen University, \\ Guangzhou, Guangdong 510060, P.R. China
}

Received December 26, 2014; Accepted September 1, 2015

DOI: $10.3892 / \mathrm{mmr} .2015 .4325$

\begin{abstract}
Tryptase exacerbates intestinal ischemia-reperfusion injury, however, the direct role of tryptase in intestinal mucosal injury and the underlying mechanism remains largely unknown. Protease-activated receptor 2 (PAR-2), commonly activated by tryptase, interacts with various adaptor proteins, including $\beta$-arrestin- 2 . The present study aimed to determine whether tryptase is capable of inducing intestinal mucosal cell injury via PAR-2 activation and to define the role of $\beta$-arrestin- 2 in the process of injury. The IEC- 6 rat intestinal epithelial cell line was challenged by tryptase stimulation. Cell viability, lactate dehydrogenase (LDH) activity and apoptosis were analyzed to determine the severity of cell injury. Injury was also evaluated following treatments with specific PAR-2 and extracellular signal-related kinases (ERK) inhibitors, and knockdown of $\beta$-arrestin-2. PAR-2, ERK and $\beta$-arrestin- 2 protein expression levels were evaluated. Tryptase treatment (100 and 1,000 ng/ml) resulted in IEC-6 cell injury, as demonstrated by significant reductions in cell viability, accompanied by concomitant increases in LDH activity and levels of cleaved caspase- 3 protein expression. Furthermore, tryptase treatment led to a marked increase in PAR-2 and phosphorylated-ERK expression, and exposure to specific PAR-2 and ERK inhibitors eliminated the changes induced by tryptase. Knockdown of $\beta$-arrestin- 2 blocked tryptase-mediated cell injury, whereas tryptase exerted no influence on $\beta$-arrestin- 2 expression in IEC- 6 cells. These data indicate that tryptase may directly damage IEC-6 cells
\end{abstract}

Correspondence to: Dr Xiaoliang Gan, Department of Anesthesiology, Zhongshan Ophthalmic Center, Sun Yat-sen University, 54 South Xianlie Road, Guangzhou, Guangdong 510060, P.R. China

E-mail: ganxiaoliang@yeah.net

*Contributed equally

Key words: tryptase, protease-activated receptor $2, \beta$-arrestin-2, intestinal injury via PAR-2 and the downstream activation of ERK, and demonstrate that the signaling pathway requires $\beta$-arrestin- 2 .

\section{Introduction}

Mast cells (MCs), containing large quantities of mediators, are widely distributed throughout gastrointestinal tracts (1) and previous studies have demonstrated that MC degranulation may exacerbate injury in a rodent model of small intestinal ischemia-reperfusion (IIR) $(2,3)$. Furthermore, tryptase, uniquely released in MC activation, is important in the process of small IIR injury (2). In addition, tryptase is involved in various types of intestinal disease, such as acute colitis and inflammatory bowel disease (4). However, the role of tryptase in the pathogenesis of small intestinal mucosal injury induced by ischemia has been difficult to define, as oxidative stress and inflammation are involved in vivo (5), and whether tryptase directly induces small intestinal mucosal injury remains to be elucidated.

Protease-activated receptor (PAR) is a family of $\mathrm{G}$ protein-coupled receptors that are activated by proteolysis, and thereby act as sensors for extracellular proteases (6). To date, four PARs have been identified, among which PAR-2 is specifically activated by trypsin and MC tryptase, while others are activated by thrombin (7). Various lines of evidence have so far demonstrated that PAR-2, highly expressed in the intestinal epithelial cells, functions in small IIR injury (8) and inhibition of tryptase following ischemia limits this by downregulation of PAR-2 (2). However, the precise mechanism of the direct role of tryptase in small intestinal mucosal injury remains to be elucidated.

$\beta$-arrestins ( $\beta$-arrestin-1 and -2 ), originally identified as terminators of the $\mathrm{G}$ protein-coupled receptorsignaling pathway, interact with PAR-2 as signal scaffolds (9) and a previous study determined that $\beta$-arrestins participate in PAR-2-mediated signal transduction (10). As a subtype of the $\beta$-arrestin family, Jacob et al (11) demonstrated that $\beta$-arrestin- 2 is essential for PAR2-induced activation of extracellular signal-related kinase (ERK) $1 / 2$ in colonocytes triggered by tryptase. Furthermore, $\beta$-arrestin-2 is significant in PAR-2-stimulated immune cell migration (12) and $\beta$-arrestin-2 may negatively regulate inflammation in polymicrobial sepsis (13). However, to the best of our knowledge, no studies have yet elucidated the role 
of $\beta$-arrestin- 2 in tryptase-induced intestinal mucosal injury under pathophysiological conditions.

Based on previous findings, it was hypothesized that tryptase alone may directly result in small intestinal mucosal injury via PAR-2 activation, and that $\beta$-arrestin- 2 may participate in the process of injury. This hypothesis was evaluated in the IEC-6 rat intestinal epithelial cell line challenged by tryptase stimulation in the presence or absence of specific PAR-2 and ERK inhibitors, as well by knockdown of $\beta$-arrestin- 2 in vitro.

\section{Materials and methods}

Reagents. IEC-6 cells were purchased from Xiehe Cell Resource Center (Beijing, China). Dulbecco's modified Eagle's medium (DMEM), DMEM with high glucose and fetal bovine serum (FBS) were purchased from Gibco Life Technologies (Carlsbad, CA, USA). Tryptase was obtained from Promega Corporation (Madison, WI, USA). PAR-2 inhibitor, FSLLRY-NH2 (FS) was purchased from Sigma-Aldrich (St. Louis, MO, USA). The 3-(4,5-dimethylthiazol-2-yl)-2,5-diphenyltetrazolium bromide (MTT) cell proliferation assay, Cytotoxicity Detection kit and LDH Detection kit were purchased from KeyGen Biotech Co., Ltd. (Nanjing, China). Specific monoclonal antibodies against p44/42 mitogen-activated protein kinases (MAPK; ERK1/2), phospho (p)-p44/42 MAPK (p-ERK1/2), total caspase-3, cleaved caspase-3, and MEK1/2 inhibitor, U0126 were purchased from Cell Signaling Technology, Inc., (Beverly, MA, USA). Mouse specific polyclonal antibodies against $\beta$-arrestin 2 (mouse/human; dilution, 1:1,000, cat no. ab54790; Abcam, Cambridge, MA, USA) and mouse specific monoclonal antibodies against PAR2 (mouse/rat/human; dilution, 1:500; cat no. sc-13504; Santa Cruz Biotechnology, Inc., Dallas, TX, USA) were used. Furthermore, rabbit monoclonal antibodies against p44/42 (human/mouse/rat; dilution, 1:2,000; cat no. 4695), rabbit monoclonal antibodies against caspase-3 (human/mouse/rat/monkey; dilution, 1:2,000; cat no. 9665), mouse monoclonal antibodies against $\beta$-actin (human, mouse, rat; dilution, 1:1,000; cat no. 3700), rabbit monoclonal antibodies against phospho (p)-p44/42 (human/mouse/rat; dilution, 1:2,000; cat no. 8544), rabbit monoclonal antibodies against cleaved caspase-3 (human/mouse/rat/monkey; dilution, 1:2,000; cat no. 9654), horseradish peroxidase (HRP)-conjugated goat anti-mouse immunoglobulin (Ig)G (dilution, 1:2,000; cat no. 4410) and HRP-conjugated goat anti-rabbit IgG (dilution, 1:2,000; cat no. 7074) were all purchased from Cell Signaling Technology, Inc., (Beverly, MA, USA). Control small interfering (si)RNA, $\beta$-arrestin-2 siRNA and siRNA Transfection Reagent were obtained from Santa Cruz Biotechnology, Inc.

Cell cultures. IEC-6 cells (rat small intestinal epithelial cell line) were cultured in DMEM with $4.5 \mathrm{~g} / 1$ glucose supplemented with 5\% FBS, $0.01 \mathrm{mg} / \mathrm{ml}$ insulin, supplemented with $100 \mathrm{U} / \mathrm{ml}$ penicillin and $100 \mu \mathrm{g} / \mathrm{ml}$ streptomycin (all from Sigma-Aldrich) in a humidified atmosphere containing $5 \% \mathrm{CO}_{2}$ at $37^{\circ} \mathrm{C}$. The culture medium was replaced twice each week and all cells used in the experiments were in passage (P)24-P50.

Cell proliferation assay. Cell proliferation was measured by MTT assay, as described previously (14). Cells were collected and seeded at a density of 5,000 cells/well, in 96-well plates, at $37^{\circ} \mathrm{C}$ in a humid chamber with $5 \% \mathrm{CO}_{2}$ for $24 \mathrm{~h}$. The cells were treated with tryptase $(0,10,100$ or $1,000 \mathrm{ng} / \mathrm{ml})$ in medium containing $1 \%$ FBS for 0, 6, 12 and $24 \mathrm{~h}$. MTT (1X; $50 \mu \mathrm{l})$ was added to each well and incubated with cells at $37^{\circ} \mathrm{C}$ for $4 \mathrm{~h}$. The medium was replaced with $150 \mu$ l dimethyl sulfoxide (DMSO) per well to dissolve the formazan crystals. The optical density (OD) was detected with a ThermoMax microplate reader (Thermo Fisher Scientific, Waltham, MA, USA) at a wavelength of $490 \mathrm{~nm}$. All experiments were performed in triplicate.

LDH activity assay. To prepare samples for the LDH activity assay, $1 \times 10^{4}$ cells were seeded in 96 -well plates for $24 \mathrm{~h}$ prior to stimulation. The cells were washed twice with PBS and exposed to different concentrations of tryptase $(0,10,100$ or 1,000 $\mathrm{ng} / \mathrm{ml}$ ) in DMEM containing 1\% FBS. After $12 \mathrm{~h}$ exposure, the supernatant was collected and centrifuged at $12,000 \mathrm{x} \mathrm{g}$ at $4^{\circ} \mathrm{C}$ for $15 \mathrm{~min}$ to remove cell debris and the tryptase. Each sample $(50 \mu \mathrm{l})$ was used to determine the activity of LDH according to the instructions of the LDH detection kit. The absorbance was measured at $440 \mathrm{~nm}$ using the ThermoMax microplate reader.

$\beta$-Arrestin-2 knockdown. The protocol followed that of previous studies with small modifications $(15,16)$. The following solutions were prepared: Solution A, for each transfection, $6 \mu 1$ siRNA duplex was diluted in $100 \mu 1$ siRNA transfection medium (reduced-serum medium); Solution B, for each transfection, $6 \mu \mathrm{l}$ siRNA transfection reagent was diluted in $100 \mu \mathrm{l}$ siRNA transfection medium. The siRNA duplex solution (solution A) was added directly to the diluted transfection reagent (solution B) using a pipette, mixed gently by repetitive pipetting, and incubated for $30 \mathrm{~min}$ at room temperature prior to use. Cells ( $2 \times 10^{5}$ per well) were seeded in a 6 -well tissue culture plate in $2 \mathrm{ml}$ antibiotic-free normal growth medium supplemented with FBS and incubated at $37^{\circ} \mathrm{C}$ in a $\mathrm{CO}_{2}$ incubator until the cells were $60-80 \%$ confluent. This took $18-24 \mathrm{~h}$. The cells were washed with $2 \mathrm{ml}$ siRNA transfection medium. For each transfection, $0.8 \mathrm{ml}$ siRNA transfection medium was added to each tube containing the siRNA transfection reagent mixture (solution $\mathrm{A}+$ solution $\mathrm{B}$ ). After incubating for $6 \mathrm{~h}$ at $37^{\circ} \mathrm{C}$ in a $\mathrm{CO}_{2}$ incubator, the transfection mixture was removed and replaced with $1 \mathrm{X}$ normal growth medium for an additional $24 \mathrm{~h}$, and the cells were subjected to western blot analysis of $\beta$-arrestin- 2 .

Western blot analysis. Cells were scraped and collected in $80 \mu 1$ lysis buffer (Beyotime Institute of Biotechnology, Haimen, China) per well and maintained at $4^{\circ} \mathrm{C}$. Cell lysate was centrifuged at $12,000 \mathrm{x}$ g at $4^{\circ} \mathrm{C}$ for $15 \mathrm{~min}$ and protein concentration in the extracts was determined by bicinchoninic acid assay. Proteins were denatured with loading buffer [30mM EDTA, 36\% (v/v) glycerol, 0.05\% (w/v) xylene cyanol FF and $0.05 \%(\mathrm{w} / \mathrm{v})$ bromophenol blue] and separated by 10 or $12 \%$ SDS-polyacrylamide gel (Beyotime Institute of Biotechnology) at $200 \mathrm{~V}$ for $40 \mathrm{~min}$. Proteins were electrotransferred to 0.22 - or $0.44-\mu \mathrm{m}$ nitrocellulose membranes (Beyotime Institute of Biotechnology) at $100 \mathrm{~V}$ for $60 \mathrm{~min}$. The membranes were blocked with $5 \%$ non-fat milk dissolved in Tris-buffered saline with Tween-20 (TBST; pH 7.5, 150 mM $\mathrm{NaCl}, 10 \mathrm{mM}$ Tris- $\mathrm{HCl}$ and $0.1 \%$ Tween-20; Beyotime Institute of Biotechnology) at room temperature for $1 \mathrm{~h}$. The membranes 
A

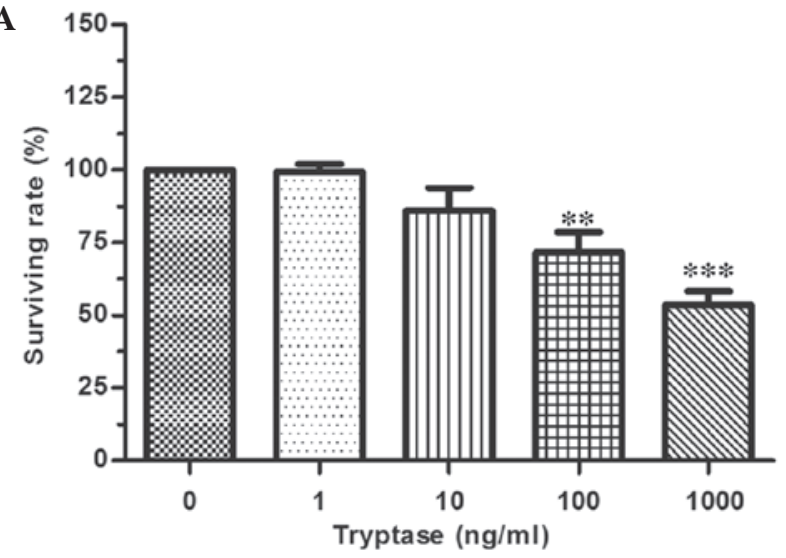

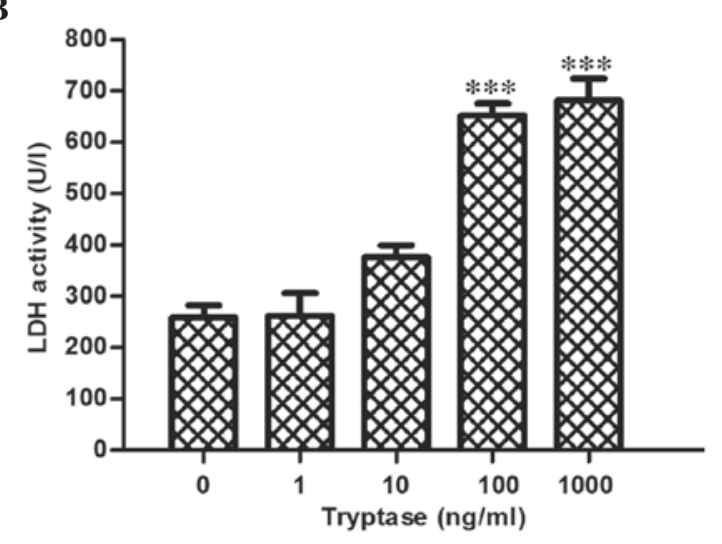

Figure 1. IEC-6 cell injury induced by different concentrations of tryptase stimulation. (A) Cell viabilities measured by MTT assay of IEC-6 cells following tryptase stimulation at different concentrations $(0,1,10,100$ and $1,000 \mathrm{ng} / \mathrm{ml}$ ) for $12 \mathrm{~h}$. (B) LDH activity resulting from IEC- 6 cells stimulated by different concentrations of tryptase $(0,1,10,100$, and $1,000 \mathrm{ng} / \mathrm{ml})$ for $8 \mathrm{~h}$. Data are expressed as percentages of the control (non-stimulated) group ( $\mathrm{n}=4)$. *" $\mathrm{P}<0.01$, ${ }^{* * * *} \mathrm{P}<0.005$ vs. control group. LDH, lactate dehydrogenase.

A

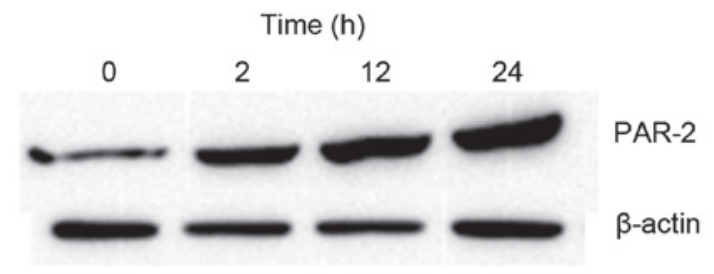

B

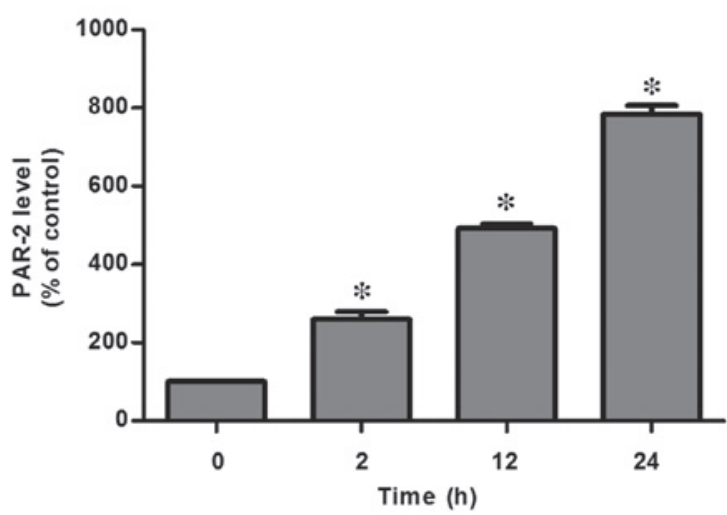

Figure 2. Time-course changes in PAR-2 protein expression in IEC-6 cells following tryptase stimulation at different time-points ( $0,2,12$ and $24 \mathrm{~h})$. (A) Band of PAR-2 protein expression in IEC-6. (B) Quantification of PAR-2 protein expression in IEC-6 cells ( $\mathrm{n}=3$ ). " $\mathrm{P}<0.05$ vs. control (non-stimulated) group. PAR-2, protease-activated receptor 2 .

were incubated with different antibodies (anti-ERK, -p-ERK, -PAR-2, - $\beta$-arrestin-2, -caspase-3, -cleaved caspase-3 and $-\beta$-actin) overnight at $4^{\circ} \mathrm{C}$. The membranes were washed at least three times with TBST and incubated with a horseradish peroxidase-conjugated anti-rabbit IgG or anti-mouse $\operatorname{IgG}$ for $1 \mathrm{~h}$ at room temperature. Densitometric analyses were performed using Quantity One software v 4.62 (Bio-Rad Laboratories, Hercules, CA, USA).

Statistical analysis. The data are presented as means \pm standard error of the mean. Analyses of variance (ANOVA) were performed using Graphpad Prism software v. 5.01 (GraphPad Software, Inc., La Jolla, CA, USA). One-way ANOVA was used for multiple comparisons, followed by the Bonferroni method and Student's t-test for unpaired values. $\mathrm{P}<0.05$ was considered to indicate a statistically significant difference.

\section{Results}

Tryptase directly induced intestinal epithelial cell injury. A previous study demonstrated that tryptase exacerbated small intestinal injury in a rodent model of IIR (17), however, in vivo results cannot determine the roles of oxidative stress and inflammation in the pathogenesis of small IIR injury (5). Thus, the aim of the present study was to investigate the direct role of tryptase alone in intestinal epithelial cells. As shown in Fig. $1 \mathrm{~A}$ and B, 100 or $1,000 \mathrm{ng} / \mathrm{ml}$ tryptase stimulation for $12 \mathrm{~h}$ reduced the cell viabilities of IEC- 6 cells, furthermore, incubating IEC- 6 cells with 100 or $1,000 \mathrm{ng} / \mathrm{ml}$ tryptase exhibited marked injury, as demonstrated by significant increases in LDH activity; however, stimulation with $10 \mathrm{ng} / \mathrm{ml}$ tryptase indicated a smaller increase in LDH activity as compared with non-stimulated cells. Furthermore, no statistical differences were observed between the 100 and $1,000 \mathrm{ng} / \mathrm{ml}$ groups. These results suggest that tryptase at higher concentrations may directly damage intestinal epithelial cells.

Tryptase enhanced PAR-2 protein expression. It has been demonstrated that PAR-2 is critical in the process of tryptase-induced inflammation in the bladder (18), thus, the involvement of PAR-2 in tryptase-mediated IEC- 6 cell injury was evaluated in the present study. PAR-2 protein expression was markedly upregulated in a time-dependent manner following exposure to $1,000 \mathrm{ng} / \mathrm{ml}$ tryptase (Fig. 2). 


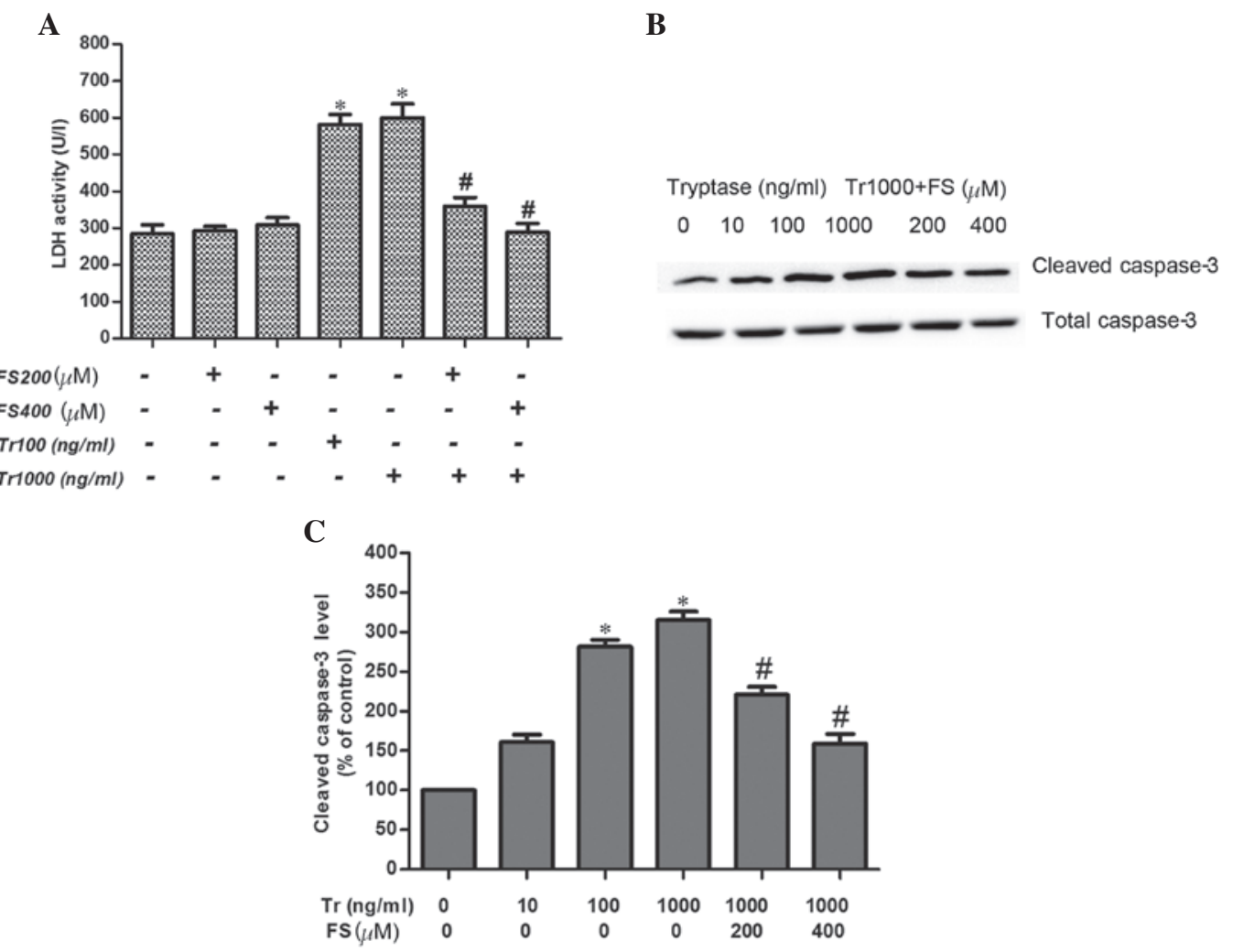

Figure 3. Effect of protease-activated receptor 2 inhibitor, FS on LDH release and the protein expression of cleaved caspase-3. (A) LDH activities of IEC-6 cells following exposure to different tryptase concentrations (100 and 1,000 ng/ml) in the presence or absence of FS (200 and $400 \mu \mathrm{M})$ for $8 \mathrm{~h}$ (n=4). (B) Band of cleaved caspase-3 protein expression in IEC- 6 cells stimulated by different concentrations of tryptase $(10,100$, and $1,000 \mathrm{ng} / \mathrm{ml})$ in the presence or absence of FS (200 and $400 \mu \mathrm{M})$ for $12 \mathrm{~h}$. (C) Variations in cleaved caspase-3 protein expression ( $=3$ ). " $\mathrm{P}<0.05$ vs. control (non-stimulated) group, "P<0.05 vs. tryptase stimulated (concentration, 1,000 ng/ml) group. FS. FSLLRY-NH2; LDH, lactate dehydrogenase; Tr, tryptase.

IEC-6 cell injury was induced by tryptase via PAR-2. As tryptase may upregulate PAR-2 protein expression, the current study evaluated whether tryptase mediates IEC- 6 cell injury via the PAR-2 signaling pathway. Thus, a specific PAR-2 inhibitor, FS, was employed. Treatment with 200 or $400 \mu \mathrm{M}$ FS blocked significant increases in LDH activity and cleaved caspase-3 protein expression when challenged by $1,000 \mathrm{ng} / \mathrm{ml}$ tryptase stimulation. Furthermore, FS alone at concentrations of 200 and $400 \mu \mathrm{l}$ had no effect on LDH activity, as compared with the control group. In addition, no significant differences between FS at concentrations of 200 and $400 \mu \mathrm{M}$ were identified $(\mathrm{P}>0.05$; Fig. $3 \mathrm{~A})$.

ERK-2 was involved in the PAR-2 signaling pathway. As MAPK is one of the downstream signal pathways of PAR-2, the current study examined the role of ERK, an MAPK. The results demonstrated that p-ERK protein expression was significantly increased and peaked $30 \mathrm{~min}$ subsequent to tryptase $(1,000 \mathrm{ng} / \mathrm{ml})$ exposure; however, $\mathrm{p}$-ERK protein expression was reduced to baseline at 60-90 min. Furthermore, as shown in Fig. 4, the specific ERK inhibitor (U0126) blocked tryptase-mediated IEC- 6 cell injury, as demonstrated by markedly downregulating LDH activity.

Role of $\beta$-arrestin- 2 in tryptase-mediated IEC- 6 cell injury. Previous studies have demonstrated that $\beta$-arrestin-2 is involved in PAR-2-associated signaling pathways, and affects the structure and function of cells (10). In the present study, the $\beta$-arrestin-2 protein expression exhibited no changes within $24 \mathrm{~h}$ of $1,000 \mathrm{ng} / \mathrm{ml}$ tryptase stimulation. Following knockdown of $\beta$-arrestin-2 (Fig. 5C and D), the IEC-6 cell injury was significantly attenuated, as demonstrated by a marked reduction in LDH activity, and the cleaved caspase-3 protein expression when compared with the control groups in the presence of $100-1,000 \mathrm{ng} / \mathrm{ml}$ tryptase (Fig. 5E-G). Additionally, after $12 \mathrm{~h}$ exposure to $1,000 \mathrm{ng} / \mathrm{ml}$ tryptase, $\beta$-arrestin-2 knockdown significantly reduced the increases in PAR-2 protein expression that were induced by tryptase (Fig. $5 \mathrm{H}$ and I). These results collectively indicate that tryptase-mediated IEC-6 cell injury via PAR-2 activity requires $\beta$-arrestin-2.

\section{Discussion}

Our previous study indicated that tryptase may aggravate small IIR injury (2), however, little is known of the direct role of tryptase in small intestinal epithelial cells. In the present study, tryptase alone was demonstrated to directly induce IEC- 6 cell injury, as demonstrated by significant increases in LDH activity and cleaved caspase-3 protein expression following exposure to 100 or $1,000 \mathrm{ng} / \mathrm{ml}$ tryptase for $12 \mathrm{~h}$. Furthermore, tryptase markedly upregulated PAR-2 expression and specifically inhibiting PAR-2 significantly abrogated tryptase-mediated injury. Furthermore, ERK was demonstrated to be involved in the process of injury, as the addition of an ERK inhibitor blocked the increase in LDH activity, which had been induced by tryptase. Notably, tryptase stimulation exerted no effects 
A

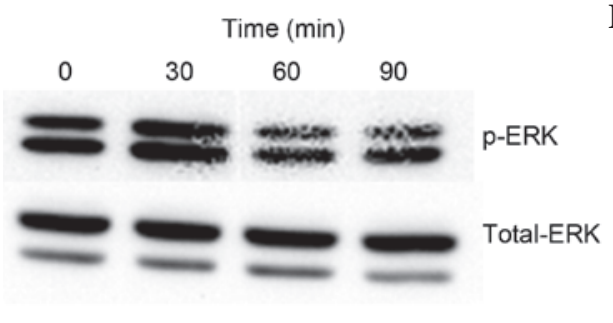

$\mathbf{C}$

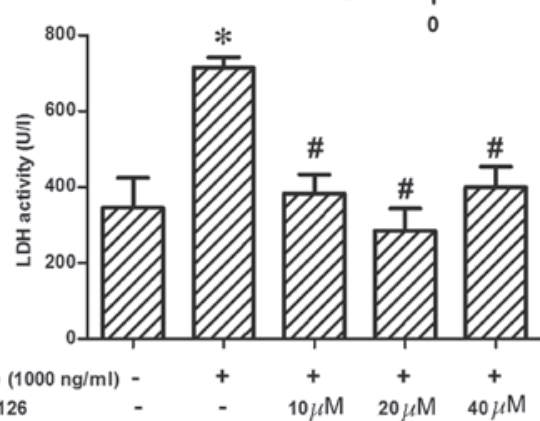

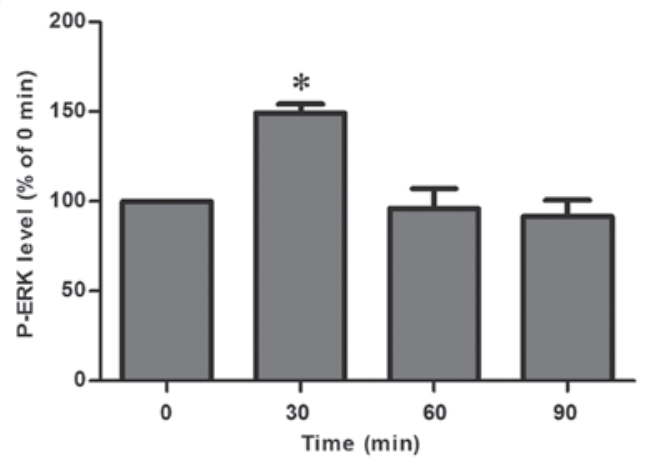

Time (min)

Figure 4. Changes in, and the role, of p-ERK in LDH release in IEC-6 cells following tryptase stimulation. (A) Band of time course changes of p-ERK protein expression in IEC-6 cells at different time-points $(0,30,60$ and $90 \mathrm{~min}$ ) with 1,000 $\mathrm{ng} / \mathrm{ml}$ tryptase stimulation. (B) Variations in p-ERK protein expression (n=3). ${ }^{*} \mathrm{P}<0.05$ vs. baseline. (C) LDH activity in IEC-6 cells exposed to $1,000 \mathrm{ng} / \mathrm{ml}$ tryptase for $8 \mathrm{~h}$ in the absence or presence of variations in specific p-ERK inhibitor, $\mathrm{U} 0126$ (10, 20 and $40 \mu \mathrm{M} ; \mathrm{n}=4)$. ${ }^{*} \mathrm{P}<0.05$ vs. control (non-stimulated) group, ${ }^{*} \mathrm{P}<0.05 \mathrm{vs} .1,000 \mathrm{ng} / \mathrm{ml}$ tryptase stimulated group (1,000 ng/ml). p-ERK, phosphorylated-extracellular signal-related kinases; LDH, lactate dehydrogenase; Tr, tryptase.

on the expression of $\beta$-arrestin-2 in IEC-6 cells whereas the injury induced by tryptase was significantly reduced following $\beta$-arrestin-2 knockdown. These results suggest that tryptase may directly result in IEC-6 cell injury by activating the PAR-2/ERK signaling pathway, and that the process of tryptase-mediated injury requires $\beta$-arrestin- 2 .

Tryptase is a protease that is released by MCs and accounts for $>25 \%$ of the total MC protein (19). Tryptase has been demonstrated to contribute to various disorders; for example, tryptase was demonstrated to be key in the development of airway hyperresponsiveness in a mouse model of asthma (20). Furthermore, tryptase contributes to colitis, as stabilizing MCs, by releasing tryptase, significantly alleviate the symptoms of colitis (21). A previous study suggests that tryptase levels in the lower gastrointestinal tract were $33.5 \mathrm{ng} / \mathrm{mg}$ (range, $8.0-154.6 \mathrm{ng} / \mathrm{mg}$ ), and the tissue tryptase concentrations were significantly increased to $55.7 \mathrm{ng} / \mathrm{mg}$ (range, $9.3-525.0$ ) subsequent to MC degranulation (22), thus, a range from 1 to $1,000 \mathrm{ng} / \mathrm{ml}$ tryptase was used in the current study. The direct mechanism by which tryptase alone contributes to IEC- 6 cell injury was assessed in the present study. It was identified that 100 or $1,000 \mathrm{ng} / \mathrm{ml}$ tryptase stimulation resulted in significant damages to IEC- 6 cells, which is consistent with a previous report demonstrating that tryptase significantly contributes to inflammatory bowel disease (4). The findings from the present study further confirm that tryptase released by $\mathrm{MC}$ activation is critical in small intestinal mucosal cell injury.

PAR-2 is highly expressed in small intestinal mucosa, our previous studies have demonstrated that inhibiting tryptase may reduce small IIR injury with associated downregulation of PAR-2 (17), furthermore, tryptase-induced itch occurs via activation of PAR-2 (23). However, since PAR-2 may be activated by various factors, including tryptase and trypsin, it is unknown whether the changes in PAR-2 are directly triggered by tryptase released from MC degranulation during IIR injury in vivo. In the present in vitro study, tryptase stimulation was indicated to induce significant increases in PAR-2 protein expression and, furthermore, the PAR-2 inhibitor, FS blocked the damage to IEC- 6 cells, which had been triggered by 100 or $1,000 \mathrm{ng} / \mathrm{ml}$ tryptase. The results indicate that tryptase-mediated intestinal mucosal injury is via the PAR-2 signaling pathway.

The activation of PAR-2 initiates multiple inflammatory responses (24), and PAR-2 activation often leads to subsequent activation of downstream MAPK signaling pathways (7), Groschwitz et al (25) demonstrated that chymase stimulation of Caco-2 BBe cells resulted in a significant increase in p38 and p44/42 (ERK1/2) activity at 15 and $60 \mathrm{~min}$ and, furthermore, that those changes were PAR-2-dependent. In the present study it was found that p-ERK expression was significantly increased and peaked at $30 \mathrm{~min}$ after tryptase stimulation, and the addition of a specific ERK inhibitor reduced the significant tryptase-induced elevations in LDH activity and cleaved caspase-3 protein expression in IEC-6 cells. The findings from the current study suggest tryptase may injure IEC-6 cells via PAR-2 activation and the downstream ERK signaling pathway.

$\beta$-arrestin-2 is an adaptor protein that may promote desensitization of G-protein signaling, it also functions as a scaffold protein in the process of PAR-2 activation (26), and this signaling pathway is crucial for PAR-2-stimulated cell migration (10). However, the role of $\beta$-arrestin- 2 in tryptase-mediated IEC-6 cell injury remains to be elucidated. In the present study, the results demonstrate that there were no changes in $\beta$-arrestin-2 protein expression resulting from tryptase stimulation; however, the tryptase-mediated IEC-6 cell injury, as well as upregulation in PAR-2 protein expression, was blocked 
A Time (h)

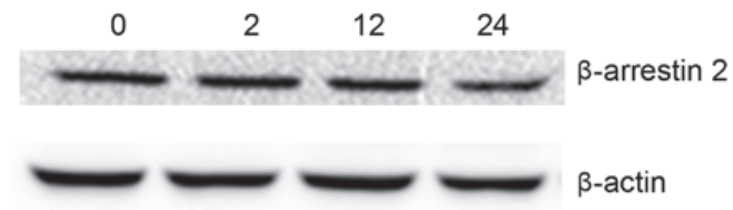

C

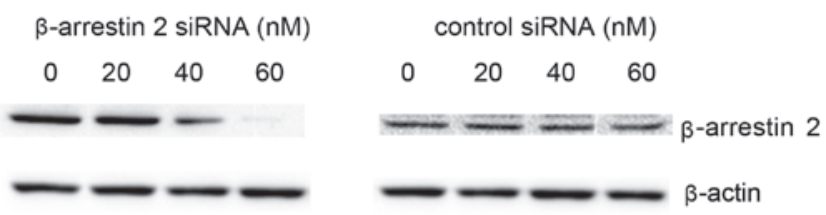

$\mathbf{E}$

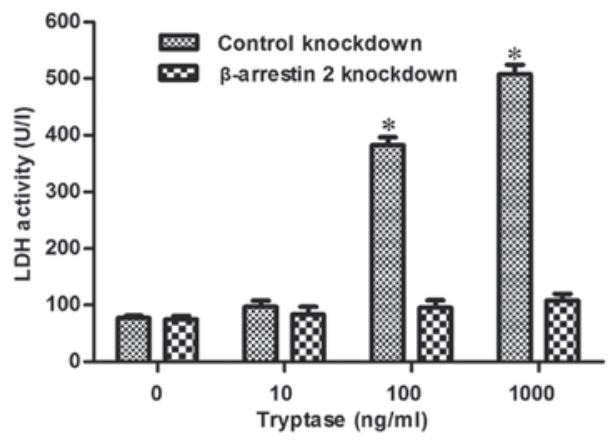

G

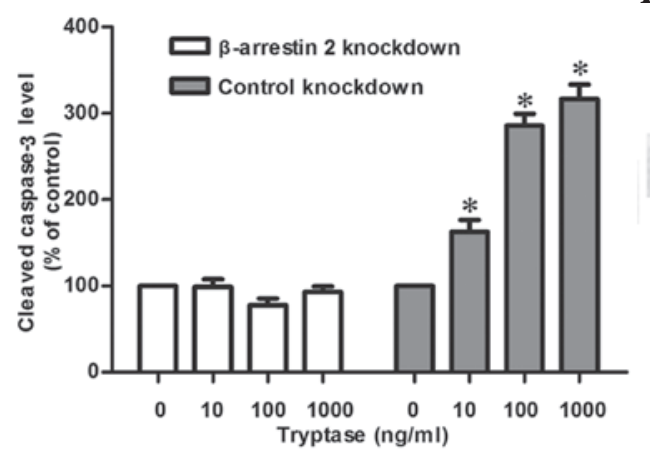

$\mathbf{H}$

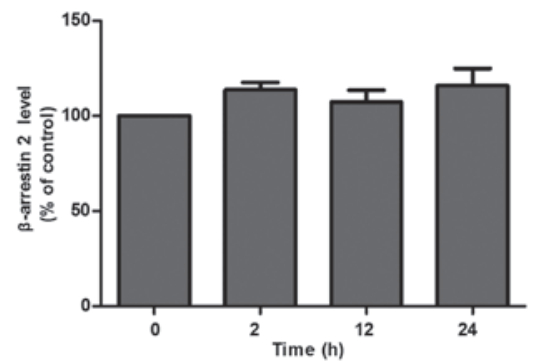

D

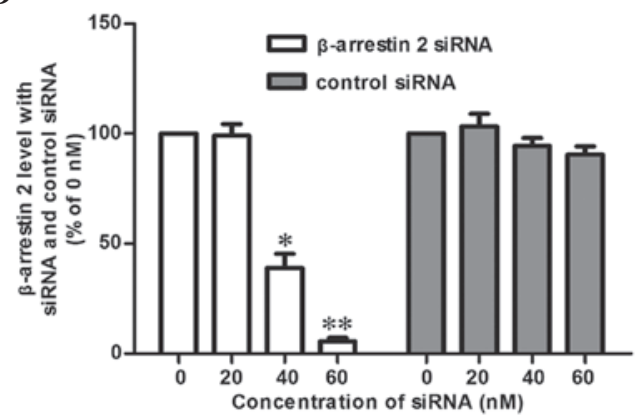

$\mathbf{F}$

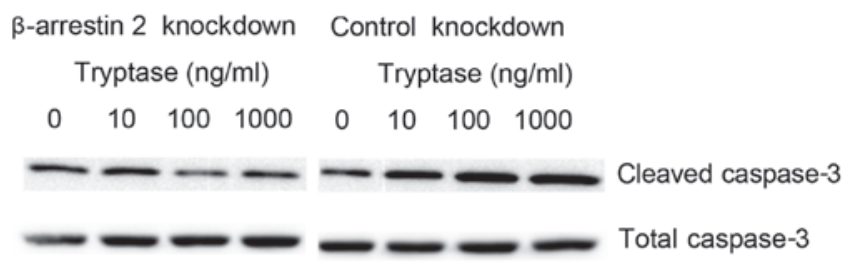

I

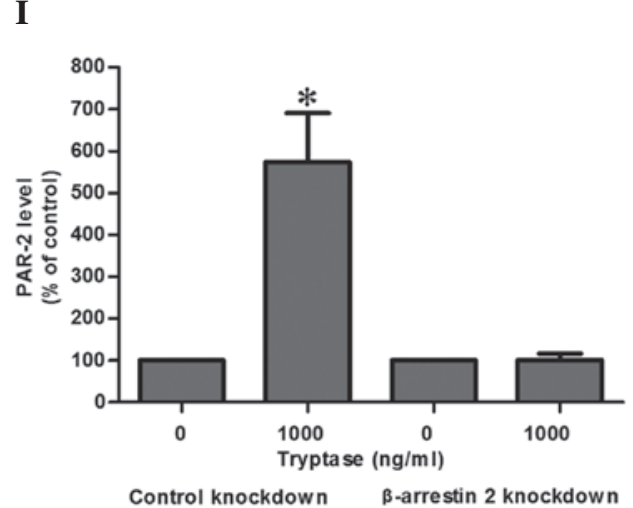

Figure 5. Roles of $\beta$-arrestin- 2 in tryptase-mediated IEC- 6 injury. (A) Band of time-course changes of $\beta$-arrestin- 2 protein expression in IEC- 6 cells at different time-points $(0,2,12$, and $24 \mathrm{~h}$ ) with $1,000 \mathrm{ng} / \mathrm{ml}$ tryptase stimulation. (B) Changes of $\beta$-arrestin- 2 protein expression ( $\mathrm{n}=3$ ). (C) Band of $\beta$-arrestin-2 protein expression following treatment with different dosages of siRNA and control siRNA reagents $(0,20,40$ and $60 \mathrm{nM})$. (D) Protein expression of $\beta$-arrestin-2 $(\mathrm{n}=3)$. ${ }^{*} \mathrm{P}<0.05 ;{ }^{* *} \mathrm{P}<0.01$ vs. control group $(0 \mathrm{nM})$. (E) LDH activities in IEC-6 cells following tryptase stimulation for $8 \mathrm{~h}$ in the absence or presence of $\beta$-arrestin-2 knockdown ( $\mathrm{n}=3$ ). ${ }^{*} \mathrm{P}<0.05$ vs. control siRNA group. (F) Cleaved caspase-3 protein expression in IEC- 6 cells stimulated by different concentrations of tryptase (10,100 and 1,000 ng/ml) in the presence or absence of $\beta$-arrestin-2 knockdown for $12 \mathrm{~h}$. (G) Changes of cleaved caspase-3 protein expression (n=3). ${ }^{*} \mathrm{P}<0.05$ vs. control siRNA group. (H) PAR-2 protein expression in IEC- 6 cells stimulated by tryptase $(1,000 \mathrm{ng} / \mathrm{ml})$ in the presence or absence of $\beta$-arrestin- 2 knockdown for $12 \mathrm{~h}$. (I) Changes of PAR-2 protein expression ( $\mathrm{n}=3$ ). " $\mathrm{P}<0.05$ vs. the control knockdown group. PAR-2, protease-activated receptor 2; LDH, lactate dehydrogenase; Tr, tryptase; siRNA, small interfering RNA.

by $\beta$-arrestin- 2 knockdown. These results are consistent with reports that the PAR-2-mediated inflammatory process in the airway is $\beta$-arrestin-2-dependent (27). The findings from the current study further suggest that $\beta$-arrestin- 2 functions as a scaffold/adaptor protein for PAR-2 activation triggered by tryptase stimulation.
There are certain limitations of the present study; firstly, four PARs are expressed in small intestinal mucosal cells, and the current study did not examine the roles of PAR-1, -3 , or -4 in IEC- 6 cell injury, as a previous study demonstrated that PAR-2 is specifically activated by tryptase. Secondly, the downstream MAPK signaling pathways induced by 
PAR-2 activation include ERK1/2, c-Jun N-terminal kinase and p38 kinases. However, only ERK1/2 was analyzed in the present study, as these kinases share the same signaling pathways (28).

In conclusion, these data suggest that tryptase alone may induce IEC-6 cell injury, via the PAR-2 and ERK signaling pathways. Furthermore, the activation of PAR-2, which is triggered by tryptase requires $\beta$-arrestin- 2 .

\section{Acknowledgements}

The present study was supported by the Fundamental Research Funds for the Central Universities of China (grant no. 12ykpy37) and Science and Technology Program of Guangzhou, China (grant no. 2014J4100172).

\section{References}

1. Brenner SA, Zacheja S, Schäffer M, Feilhauer K, Bischoff SC and Lorentz A: Soluble CD14 is essential for lipopolysaccharide-dependent activation of human intestinal mast cells from macroscopically normal as well as Crohn's disease tissue. Immunology 143: 174-183, 2014.

2. Gan X, Liu D, Huang P, Gao W, Chen X and Hei Z: Mast-cell-releasing tryptase triggers acute lung injury induced by small intestinal ischemia-reperfusion by activating PAR-2 in rats. Inflammation 35: 1144-1153, 2012.

3. Gan X, Su G, Zhao W, Huang P, Luo G and Hei Z: The mechanism of sevoflurane preconditioning-induced protections against smal intestinal ischemia reperfusion injury is independent of mast cell in rats. Mediators Inflamm 2013: 378703, 2013.

4. Hamilton MJ, Sinnamon MJ, Lyng GD, Glickman JN, Wang X, Xing W, Krilis SA, Blumberg RS, Adachi R, Lee DM and Stevens RL: Essential role for mast cell tryptase in acute experimental colitis. Proc of the Natl Acad Sci USA 108: 290-295, 2011.

5. Zhao W, Zhou S, Yao W, Gan X, Su G, Yuan D and Hei Z: Propofol prevents lung injury after intestinal ischemia-reperfusion by inhibiting the interaction between mast cell activation and oxidative stress. Life Sci 108: 80-87, 2014.

6. Zhao P, Metcalf $M$ and Bunnett NW: Biased signaling of protease-activated receptors. Front Endocrinol (Lausanne) 5: 67, 2014.

7. Rothmeier AS and Ruf W: Protease-activated receptor 2 signaling in inflammation. Semin Immunopathol 34: 133-149, 2012.

8. Yoshida N, Takagi T, Isozaki Y, Suzuki T, Ichikawa H and Yoshikawa T: Proinflammatory role of protease-activated receptor-2 in intestinal ischemia/reperfusion injury in rats. Mol Med Rep 4: 81-86, 2011

9. Kang DS, Tian X and Benovic JL: Role of $\beta$-arrestins and arrestin domain-containing proteins in $\mathrm{G}$ protein-coupled receptor trafficking. Curr Opin Cell Biol 27: 63-71, 2014.

10. Zoudilova M, Min J, Richards HL, Carter D, Huang T and DeFea KA: beta-Arrestins scaffold cofilin with chronophin to direct localized actin filament severing and membrane protrusions downstream of protease-activated receptor-2. J Biol Chem 285: 14318-14329, 2010.

11. Jacob C, Yang PC, Darmoul D, Amadesi S, Saito T, Cottrell GS, Coelho AM, Singh P, Grady EF, Perdue M and Bunnett NW: Mast cell tryptase controls paracellular permeability of the intestine. Role of protease-activated receptor 2 and beta-arrestins. J Biol Chem 280: 31936-31948, 2005.
12. Ge L, Shenoy SK, Lefkowitz RJ and DeFea K: Constitutive protease-activated receptor-2-mediated migration of MDA MB-231 breast cancer cells requires both beta-arrestin-1 and -2 J Biol Chem 279: 55419-55424, 2004.

13. Fan H, Bitto A, Zingarelli B, Luttrell LM, Borg K, Halushka PV and Cook JA: Beta-arrestin 2 negatively regulates sepsis-induced inflammation. Immunology 130: 344-351, 2010.

14. Ho J, Du Y, Wong OG, Siu MK, Chan KK and Cheung AN: Downregulation of the gli transcription factors regulator kif7 facilitates cell survival and migration of choriocarcinoma cells. PLoS One 9: e108248, 2014.

15. Du RW, Du RH and Bu WG: $\beta$-Arrestin 2 mediates the anti-inflammatory effects of fluoxetine in lipopolysaccharide-stimulated microglial cells. J Neuroimmune Pharmacol 9: 582-590, 2014.

16. Lakshmikanthan V, Zou L, Kim JI, Michal A, Nie Z, Messias NC, Benovic JL and Daaka Y: Identification of betaArrestin2 as a corepressor of androgen receptor signaling in prostate cancer. Proc Natl Acad Sci USA 106: 9379-9384, 2009.

17. Liu D, Gan X, Huang P, Chen X, Ge M and Hei Z: Inhibiting tryptase after ischemia limits small intestinal ischemia-reperfusion injury through protease-activated receptor 2 in rats. J Trauma Acute Care Surg 73: 1138-1144, 2012.

18. Wang ZY, Wang P and Bjorling DE: Role of mast cells and protease-activated receptor- 2 in cyclooxygenase- 2 expression in urothelial cells. Am J Physiol Regul Integr Comp Physiol 297: R1127-R1135, 2009.

19. Pejler G, Rönnberg E, Waern I and Wernersson S: Mast cell proteases: Multifaceted regulators of inflammatory disease. Blood 115: 4981-4990, 2010.

20. Cui Y, Dahlin JS, Feinstein R, Bankova LG, Xing W, Shin K, Gurish MF and Hallgren J: Mouse mast cell protease- 6 and MHC are involved in the development of experimental asthma. J Immunol 193: 4783-4789, 2014.

21. Eliakim R, Karmeli F, Okon E and Rachmilewitz D: Ketotifen effectively prevents mucosal damage in experimental colitis. Gut 33: 1498-1503, 1992.

22. Hagel AF, deRossi T, Zopf Y, Konturek P, Dauth W, Kressel J, Hahn EG and Raithel M: Mast cell tryptase levels in gut mucosa in patients with gastrointestinal symptoms caused by food allergy. Int Arch Allergy Immunol 160: 350-355, 2013.

23. Tsujii K, Andoh T, Ui H, Lee JB and Kuraishi Y: Involvement of tryptase and proteinase-activated receptor-2 in spontaneous itch-associated response in mice with atopy-like dermatitis. J Pharmacol Sci 109: 388-395, 2009.

24. Ebeling C, Forsythe P, Ng J, Gordon JR, Hollenberg M and Vliagoftis $\mathrm{H}$ : Proteinase-activated receptor 2 activation in the airways enhances antigen-mediated airway inflammation and airway hyperresponsiveness through different pathways. J Allergy Clin Immunol 115: 623-630, 2005.

25. Groschwitz KR, Wu D, Osterfeld H, Ahrens R and Hogan SP: Chymase-mediated intestinal epithelial permeability is regulated by a protease-activating receptor/matrix metalloproteinase-2-dependent mechanism. Am J Physiol Gastrointest Liver Physiol 304: G479-G489, 2013.

26. Zoudilova M, Kumar P, Ge L, Wang P, Bokoch GM and DeFea KA: Beta-arrestin-dependent regulation of the cofilin pathway downstream of protease-activated receptor-2. J Biol Chem 282: 20634-20646, 2007.

27. Nichols HL, Saffeddine M, Theriot BS, Hedge A, Polley D, El-Mays T, Vliagoftis H, Hollenberg MD, Wilson EH, Walker JK and DeFea KA: $\beta$-Arrestin- 2 mediates the proinflammatory effects of proteinase-activated receptor-2 in the airway. Proc Natl Acad Sci USA 109: 16660-16665, 2012.

28. Darling NJ and Cook SJ: The role of MAPK signalling pathways in the response to endoplasmic reticulum stress. Biochim Biophys Acta 1843: 2150-2163, 2014. 